Nepalese Vet J. 34: 85-94

\title{
EFFECT OF BREED AND GENDER ON HEMATOLOGICAL PARAMETERS AND SOME SERUM BIOCHEMICAL PROFILES OF APPARENTLY HEALTHY INDIGENOUS SHEEP OF NEPAL
}

\author{
${ }^{1}$ N. Amatya Gorkhali* ${ }^{2}$ S. Khanal, ${ }^{1}$ S. Sapkota, ${ }^{3}$ M. Prajapati, ${ }^{1}$ Y. K. Shrestha and ${ }^{3}$ D. R. Khanal \\ ${ }^{1}$ Animal Breeding Division, Nepal Agriculture Research Council, Khumaltar, Nepal \\ ${ }^{2}$ Institute of Agriculture and Animal Science, Rampur, Nepal \\ ${ }^{3}$ Animal Health Research Division, Khumaltar, Nepal \\ (*email: neenagorkhali@hotmail.com)
}

\begin{abstract}
This research was conducted to investigate the effect of some factors such as breed and sex on biochemical and serum parameters as well as to establish normal physiological reference values for indigenous breed of sheep of Nepal. Blood sample were collected from 25 apparently healthy sheep (11 males and 14 females) from on station flock at Khumaltar, Nepal Agriculture Research Council (NARC) were used. In case of serum biochemical parameters, overall LS mean for total Protein (TP) was less than physiological range while Albumin (Alb) was recorded higher than normal physiological range. The breed differences were observed in TP where Lampuch hre sheep (lowland sheep) showed the lower value than hill sheep breeds (Baruwal and Kage sheep) taken in the study. The same breed exhibited gender variation in the same parameter with values in males were significantly higher $(P<0.05)$ than females. Comparing LS Mean for Alb and Phosphrous $(P)$ for Nepalese sheep, value recorded for females were found to be significantly higher $P(<0.05)$ than males in case of serum Alb while serum $P$ was significantly lower $(P<0.05)$ in females. For $R B C$ indices, Nepalese sheep exhibited higher Mean Corpuscular Haemoglobin Concentration (MCHC) was higher than normal physiological range. LYM and NE value was significantly higher in Kage breed in comparison to Lampuchhre and Baruwal. The highly significant gender variation for Mean Corpuscular Volume $(M C V)(P<0.01)$ and Mean Corpuscular Hemoglobin $M C H(P<0.05)$ where female showed the higher value than males. The result of the preliminary study revealed the breed and sex variation in case of hematological and biochemical indices Further research with more number of samples is warranted for concrete information which could be used to monitor animal health status to improve the management and conservation of these breeds.
\end{abstract}

Keywords: sheep, Nepalese breed, hematological parameters, serum biochemical indices

\section{INTRODUCTION}

Hematological tests are important tools for evaluation of physiological and health status of farm animals (Oduye, 1976). Hematological analyses in farm animals have been extensively discussed as an essential part of clinical examination often pointing to a specific differential diagnosis or suggesting a prognosis (Braun et al., 2010; Polizopoulou, 2010).

Sheep are an important livestock commodity in the country, particularly for the hills and mountains. There are total 0.79 million sheep in the country (Central Bureau of Statistics, 2016); out of which five to ten percent is exotic (pure or crossbred) and remaining is indigenous suggesting more 
contributions come from indigenous breeds (Neopane and Pokhrel, 2005). The raising of sheep in Nepal is primarily destined to the production of wool, meat, manure and draught; particularly in the hills and mountains. Considering the high economic values of sheep among the livestock farming system, it is important to perform clinical and para-clinical examination to guarantee sanitary strategies control, prevention or treatment of diseases and to assure good management practices. It is well-recognized that hematological parameters in sheep show several variations in relation to disease, nutrition, management system, physiologic status (Šimpragaa et al., 2013); stress, location and season (Oramari et al., 2014); sex, breed, age (Addass et al., 2010, 2012). Moreover, the productivity and reproductive efficiency of animals are co-related with the blood parameters and values are affected by internal and external environment (Oramari et al., 2014). These differences have under scored the need to establish appropriate physiological baseline values for livestock, which could be used in the realistic evaluation of the management practice, nutrition and diagnosis of health condition as well as in determining the physiological status of animals (Šimpragaa et al., 2013).
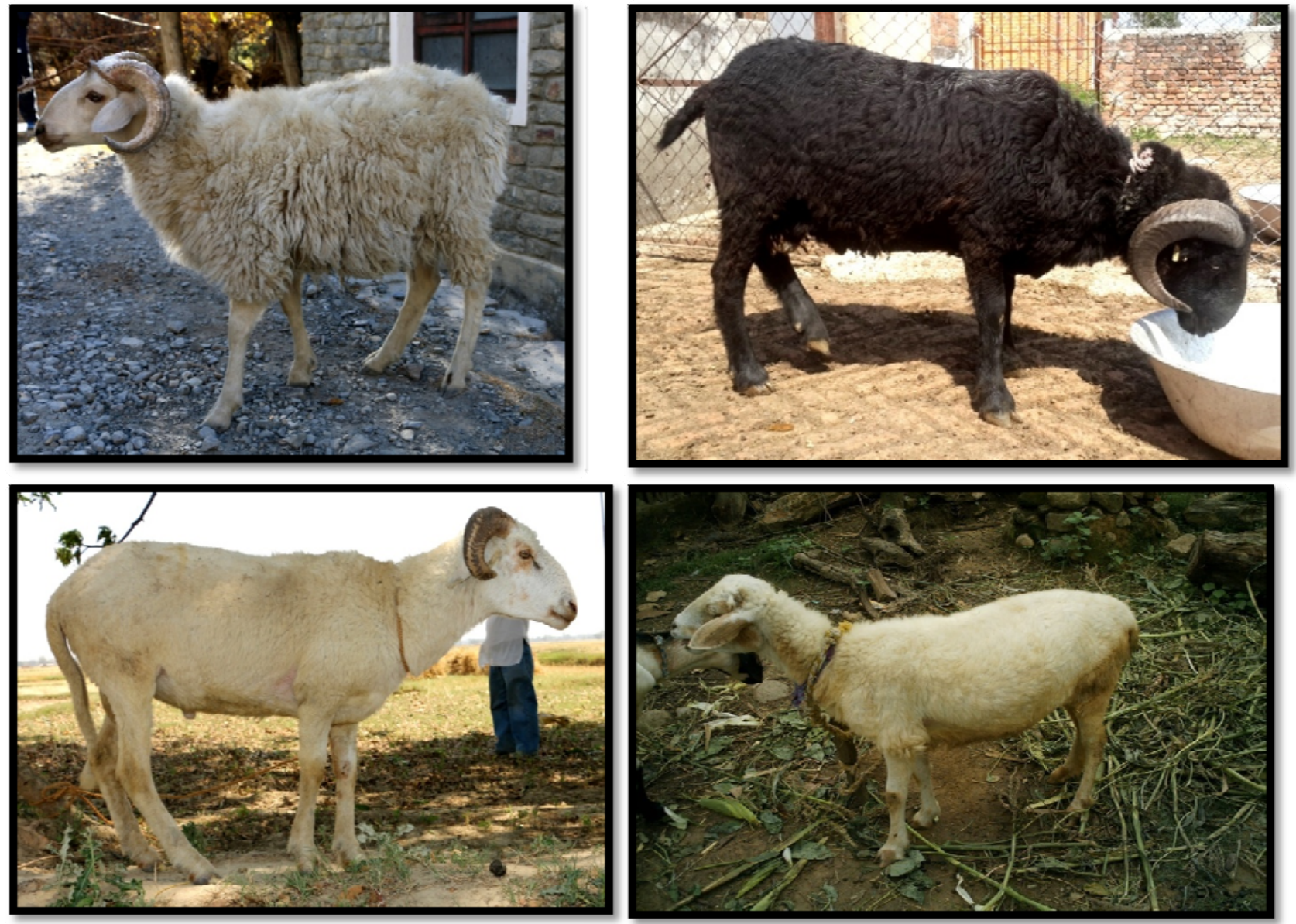

Fig. 1:Four breeds of Nepalese sheep: A. Bhyanglung, B. Baruwal, C. Lampuchhre, D. Kage

In this study, we have focused on three out of four breeds of Nepalese sheep (Fig1.) according to their economic contribution and/ or population, namely Baruwal (63\%), Kage (21\%) and Lampuchhre (12\%). Baruwal sheep are found from mid hill to high hill; Kage are distributed from low land to mid hills; and Lampuchhre are predominant in low land. These animals particularly 
adapted to their existing environment and exhibit disease resilience against the economic diseases. Although considerable information is available on the normal hematological parameters of exotic sheep breeds under their home tract environment and management conditions (Tibbo et al., 2004), these values could not serve as baseline information for comparison in conditions of nutrient deficiency, physiological and health status of indigenous sheep breed in Nepalese condition. Hence, the aim of this study was to evaluate the variation on age and breed on some hematological and biochemical parameters of indigenous sheep breeds of Nepal and moreover to bring forth normal hematological and biochemical reference values for these breeds.

\section{MATERIALS AND METHODS}

\section{Experimental location and climatic condition}

In this study, three Nepalese sheep breeds, namely Baruwal, Kage and Lampuchhre, was used which were maintained at farm of Animal Breeding Division, Nepal Agriculture Research Council (NARC), Khumaltar. All the animals considered for study were around one year of age. The average minimum and maximum temperature during the sample collection season was $9.7^{\circ} \mathrm{C}$ and $18.5^{\circ} \mathrm{C}$ respectively. Relative humidity was $48 \%$, pressure $1.0037 \mathrm{~atm}$, wind speed $1.1 \mathrm{~m} / \mathrm{s}$ and wind degree $231.501^{\circ}$.

\section{Sample Collection}

Blood samples were collected from the jugular vein of 25 apparently healthy sheep (11 males and 14 females) of different breeds (Baruwal, Kage, and Lampuchhre). Average live weights of adult males and females were $48 \mathrm{~kg}$ and $30 \mathrm{~kg}$ respectively. The sheep were bled through jugular vein and $10 \mathrm{ml}$ blood collected. $3 \mathrm{ml}$ of the blood samples were collected into in anticoagulant free serum vial and allowed to clot at room temperature within $3 \mathrm{hrs}$ of collection. Serum samples was obtained through centrifugation at $8000 \mathrm{rpm}$ for 10 minutes and stored at $-20^{\circ} \mathrm{C}$ for biochemical studies. The remaining $7 \mathrm{ml}$ of blood samples were deposited in vacutainer containing EDTA for hematological studies.

Table1:List of individual number for different breeds of indigenous sheep

\begin{tabular}{|c|c|c|c|}
\hline Breed & & & Total \\
\hline Baruwal & & & 9 \\
\hline Kage & & & 11 \\
\hline Lampuchhre & & & 5 \\
\hline & Male & 11 & \\
\hline & Female & 14 & \\
\hline
\end{tabular}

\section{Haematological analysis}

Hematological parameters such as RBC indices i.e. Total Red Blood Cell count (RBC), Haemoglobin ( $\mathrm{Hb})$, Packed Cell Volume (PCV), Mean Corpuscular Volume (MCV), Mean Corpuscular Haemoglobin (MCH), Mean Corpuscular Haemoglobin Concentration (MCHC) and WBC indices i.e. Total White Blood Cell Count (WBC) and differential countwere estimated by fully automated Abacus Junior Vet 5 Haematology Analyser at Central Veterinary Laboratory Tripureswore. 


\section{Biochemical analysis}

The biochemical metabolites were analyzed using Randox kits on manually operated colorimeter. The serum biochemical metabolites measured were Total Protein $(\mathrm{mg} / \mathrm{dl})$ by Biuret, albumin $(\mathrm{mg} / \mathrm{dl})$ by Bromocresol Green dye binding method, glucose $(\mathrm{mg} / \mathrm{dl})$ by GOD-PAP method and Calcium (mg/dl) by ARSENAZO 111 method and phosphorus by UV method.

\section{Statistical analysis}

Least Square Mean values and standard errors were calculated using Harvey (1990) computer software package based on fixed effect model stated by Henderson (1953). One-way ANOVA was used to assess the statistical difference between male and female and among breed variation.

Where,

$$
Y_{i j k}=\mu+a_{i}+b_{j}+e_{i j k}
$$

$$
\begin{aligned}
& Y_{i j k}=\text { Observational value of the } k^{\text {th }} \text { animal } \\
& \mu=\text { Overall mean } \\
& a_{i}=i \text { th effect of breed (Kage, Lampuchhre and Baruwal) } \\
& b_{j}=j \text { th effect of sex (Male and Female) } \\
& e_{i j k}=\text { error term }
\end{aligned}
$$

\section{RESULT}

\section{Hematological parameters}

\section{Red Blood Cell indices}

Red Blood Cell indices i.e. total Red Blood Cell count (RBC), Haemoglobin (Hb), Packed Cell Volume (PCV), Mean Corpuscular Volume (MCV), Mean Corpuscular Haemoglobin (MCV), Mean Corpuscular Haemoglobin Concentration (MCHC) were found to be $12.74 \pm 1.9010^{12} / 1$, $14.97 \pm 1.90 \mathrm{~g} / \mathrm{l}, 36.74 \pm 4.76 \%, 28.92 \pm 2.41 \mathrm{fl}, 11.81 \pm 0.82 \mathrm{pg}, 40.52 \pm 2.98 \mathrm{~g} / \mathrm{dl}$ respectively. Nepalese sheep exhibited higher MCHC than normal physiological range $(31-34 \mathrm{~g} / \mathrm{dl})$. Highly significant gender variation was observed for $\mathrm{MCV}(\mathrm{P}<0.01)$ and $\mathrm{MCH}(\mathrm{P}<0.05)$ where females showed comparatively higher value than males.

Table2:Nepalese Sheep Red Blood Cell indices (Least Square \pm Standard Error)

\begin{tabular}{llllllll}
\hline Factors & No. & $\mathbf{R B C}\left(\mathbf{1 0}^{\mathbf{1 2}} \mathbf{l}\right)$ & $\mathbf{H b}(\mathbf{m g} / \mathbf{d l})$ & $\mathbf{P C V}(\mathbf{\%})$ & $\mathbf{M C V}(\mathbf{f l})$ & $\mathbf{M C H}(\mathbf{p g})$ & $\mathbf{M C H C}(\mathbf{g} / \mathbf{d l})$ \\
\hline $\begin{array}{llllll}\text { Overall } \\
\text { Mean }\end{array}$ & 25 & $12.61 \pm 0.36$ & $14.7 \pm 0.38$ & $36.29 \pm 1.01$ & $28.82 \pm 0.42$ & $11.79 \pm 0.17$ & $40.62 \pm 0.67$ \\
Breed & & $\mathrm{NS}$ & $\mathrm{NS}$ & $\mathrm{NS}$ & $\mathrm{NS}$ & $\mathrm{NS}$ & $\mathrm{NS}$ \\
Baw & 9 & $12.11 \pm 0.57$ & $14.3 \pm 0.60$ & $35.92 \pm 1.59$ & $29.61 \pm 0.67$ & $11.92 \pm 0.26$ & $40.16 \pm 1.05$ \\
Kag & 11 & $13.85 \pm 0.54$ & $16 \pm 0.57$ & $38.57 \pm 1.51$ & $27.94 \pm 0.63$ & $11.59 \pm 0.25$ & $40.65 \pm 1$ \\
Lam & 5 & $11.87 \pm 0.77$ & $14 \pm 0.8$ & $34.39 \pm 2.14$ & $28.90 \pm 0.90$ & $11.86 \pm 0.34$ & $41.05 \pm 1.41$ \\
Sex & & $*$ & $\mathrm{NS}$ & $\mathrm{NS}$ & $* *$ & $*$ & $\mathrm{NS}$ \\
Male & 11 & $13.37 \pm 0.52$ & $15.2 \pm 0.55$ & $36.64 \pm 1.46$ & $27.31 \pm 0.61$ & $11.41 \pm 0.24$ & $40.89 \pm 0.96$ \\
Female & 14 & $11.84 \pm 0.50$ & $14.3 \pm 0.50$ & $35.94 \pm 1.39$ & $30.33 \pm 0.59$ & $12.16 \pm 0.23$ & $40.34 \pm 0.91$ \\
\hline CV & & 13.57 & 12.04 & 13.01 & 6.95 & 6.68 & 7.77 \\
\hline
\end{tabular}

$\mathrm{Mg} / \mathrm{dl}=$ milligram per deciliters, $\mathrm{fl}=$ femtolitre, $\mathrm{pg}=$ pictogram, $\mathrm{g} / \mathrm{dl}=$ gram per deciliters, NS=Not Significant, $\mathrm{CV}=$ Coefficient of Variation 


\section{White Blood Cell indices}

White Blood Cell indices i.e. White Blood Cell Count (WBC), Lymphocytes (LYM), Monocytes (MO), Neutrophils (NE) were found to be $10.56 \pm 3.8710^{9} / 1,46.81 \pm 18.59 \%, 0.50 \pm 00 \%$, and $52.69 \pm 18.59 \%$ respectively while Eosinophils and Basophils were undetectable for Nepalese sheep. LYM and NE value was significantly higher in Kage breed in comparison to Lampuchhre and Baruwal. The highly significant gender variation for $\mathrm{MCV}(\mathrm{P}<0.01)$ and $\mathrm{MCH}(\mathrm{P}<0.05)$ where female showed the higher value than males.

Table 3: Nepalese sheep White Blood Cell Indices (Least Square \pm Standard Error)

\begin{tabular}{lllll}
\hline Factors & No. of individual & WBC (10 $/ \mathbf{l})$ & LYM $(\%)$ & NE (\%) \\
\hline Overall Mean & 25 & $10.31 \pm 0.84$ & $49.02 \pm 3.23$ & $50.48 \pm 3.23$ \\
Breed & & NS & $*$ & $*$ \\
Baw & 9 & $10.77 \pm 1.33$ & $56.94 \pm 5.10$ & $42.56 \pm 5.10$ \\
Kag & 11 & $11.35 \pm 1.26$ & $36.89 \pm 4.38$ & $62.60 \pm 4.82$ \\
Lam & 5 & $8.81 \pm 1.79$ & 53.23 .6 .85 & $46.26 \pm 6.86$ \\
Sex & & NS & NS & NS \\
Male & 11 & 10.961 .21 & $53.74 \pm 4.67$ & $45.76 \pm 4.67$ \\
Female & 14 & $9.66 \pm 1.16$ & $44.30 \pm 4.45$ & $55.19 \pm 4.45$ \\
\hline CV & & 37.75 & 32.62 & 28.98 \\
\hline
\end{tabular}

NS=Not Significant $\quad \mathrm{CV}=$ Coefficient of Variation

\section{Biochemical indices}

The overall Least Square (LS) mean for Total protein (TP), Albumin (Alb), Glucose (Glu), Calcium (Cal) and Phosphrous (P) were $5.94 \pm 0.53 \mathrm{mg} / \mathrm{dl}, \quad 3.15 \pm 0.06 \mathrm{mg} / \mathrm{dl}, \quad 55.66 \pm 12.89 \mathrm{mg} / \mathrm{dl}$, $11.39 \pm 0.77 \mathrm{mg} / \mathrm{dl}$ and $6.60 \pm 1.60 \mathrm{mg} / \mathrm{dl}$ respectively. The result of present study revealed that the overall LS mean for TP for Nepalese breed was lower while that for Alb was higher than physiological range. The breed differences were observed in TP where Lampuchhre sheep (lowland sheep) showed the lower value than hill sheep breeds (Baruwal and Kage sheep) taken in the study. The same breed exhibited gender variation in the same parameter with values in males were significantly higher $(\mathrm{P}<0.05)$ than females. Comparing LS Mean for Alb and $\mathrm{P}$ for Nepalese sheep, value recorded for females were found to be significantly higher $\mathrm{P}(<0.05)$ than males in case of serum Alb while serum $P$ was females.

Table 4: Nepalese sheep biochemical indices (Least Square \pm Standard Error)

\begin{tabular}{lllllll}
\hline Factors & No. & TP $(\mathbf{m g} / \mathbf{d l})$ & Alb $(\mathbf{m g} / \mathbf{d l})$ & Glu (mg/dl) & Cal (mg/dl) & Phos (mg/dl) \\
\hline $\begin{array}{l}\text { Overall } \\
\text { Mean }\end{array}$ & 25 & $5.88 \pm 0.10$ & $3.10 \pm 0.06$ & $56.55 \pm 2.94$ & $11.41 \pm 0.18$ & $6.60 \pm 0.31$ \\
Breed & & NS & NS & NS & NS & NS \\
Baw & 9 & $5.73 \pm 0.16$ & $3.06 \pm 0.08$ & $54.37 \pm 4.48$ & $11.45 \pm 0.28$ & $6.27 \pm 0.48$ \\
Kag & 11 & $6.32 \pm 0.17$ & $3.16 \pm 0.08$ & $57.29 \pm 4.52$ & $11.45 \pm 0.28$ & $7.36 \pm 0.48$ \\
Lam & 5 & $5.60 \pm 0.22$ & $3.07 \pm 0.11$ & $57.98 \pm 6.09$ & $11.33 \pm 0.38$ & $6.17 \pm 0.65$ \\
Sex & & $*$ & $*$ & NS & NS & $*$ \\
Male & 11 & $5.91 \pm 0.15$ & $2.97 \pm 0.08$ & $52.68 \pm 4.14$ & $11.31 \pm 0.26$ & $7.59 \pm 0.44$ \\
Female & 14 & $5.86 \pm 0.15$ & $3.23 \pm 0.08$ & $60.41 \pm 4.16$ & $11.51 \pm 0.26$ & $5.61 \pm 0.44$ \\
\hline CV & & 8.27 & 8.01 & 24 & 7.37 & 21.68 \\
\hline
\end{tabular}

$\mathrm{mg} / \mathrm{dl}=$ milligram per deciliters, NS=Not Significant,$\quad C V=$ Coefficient of Variation 
Table 5:Range of hematological and serum biochemical indices of Nepalese sheep

\begin{tabular}{|c|c|c|c|c|c|}
\hline \multicolumn{6}{|c|}{ Haematology (RBC Indices) } \\
\hline Parameters & Unit & Nepalese sheep range & $\begin{array}{l}\text { Normal } \\
\text { sheep* }\end{array}$ & range & of \\
\hline RBC(Total Count) & $\left(10^{12} / 1\right)$ & $9.56-16.96$ & $9-15.8$ & & \\
\hline $\mathrm{Hb}$ & $(\mathrm{mg} / \mathrm{dl})$ & $119-199$ & $9-15$ & & \\
\hline PCV & $\%$ & $26.22-47.47$ & $27-45$ & & \\
\hline $\mathrm{MCV}$ & fl (femto litre) & $26-34$ & $28-40$ & & \\
\hline $\mathrm{MCH}$ & pg (picogram) & $10.4-13.6$ & $8-12$ & & \\
\hline $\mathrm{MCHC}$ & $\mathrm{g} / \mathrm{dl}$ & $35.71-48.4$ & $31-34$ & & \\
\hline \multicolumn{6}{|c|}{ Haematology (WBC Indices) } \\
\hline WBC (Total Count) & $\left.10^{9} / 1\right)$ & $5.26-19.8$ & $4-12$ & & \\
\hline Lymphocyte & $\%$ & $0-71$ & $40-70$ & & \\
\hline Neutrophile & $\%$ & $28.5-65$ & $10-63$ & & \\
\hline Monocyte & $\%$ & 0.5 & $0-6$ & & \\
\hline Eosinophile & $\%$ & 0 & $1-8$ & & \\
\hline Basophile & $\%$ & 0 & $0-3$ & & \\
\hline \multicolumn{6}{|l|}{ Biochemistry } \\
\hline $\mathrm{TP}$ & $(\mathrm{mg} / \mathrm{dl})$ & $4.93-7.04$ & $6-7.9$ & & \\
\hline Alb & $(\mathrm{mg} / \mathrm{dl})$ & $2.68-3.54$ & $2.4-3$ & & \\
\hline Glu & $(\mathrm{mg} / \mathrm{dl})$ & $33.33-75$ & $42-76$ & & \\
\hline Cal & $(\mathrm{mg} / \mathrm{dl})$ & $10.03-12.61$ & $11.5-12$ & & \\
\hline $\mathrm{P}$ & $(\mathrm{mg} / \mathrm{dl})$ & $5.05-8.42$ & $5-7.3$ & & \\
\hline
\end{tabular}

*Adapted from: Research Animal Resources [RAR] (2009)

\section{DISCUSSION}

Hemoglobin is the iron-containing oxygen-transporting protein in the red blood cells of vertebrates. The deficiency of hemoglobin in the red blood cells decreases blood oxygen-carrying capacity leading to symptoms of anemia while higher $\mathrm{Hb}$ value indicates higher oxygen carrying capacity of the blood and greater ability to resist disease infection. Nepalese Breed exhibited higher concentration of $\mathrm{Hb}(14.7 \pm 0.38 \mathrm{mg} / \mathrm{dl})$ than Northern Nigeria sheep breed i.e $12.90 \pm 0.22 \mathrm{mg} / \mathrm{dl}$ (Njidda et al., 2014) and Iranian sheep breed i.e. $8.93 \pm 1.07 \mathrm{mg} / \mathrm{dl}$ (Oramari et al., 2014) which suggests Nepalese Sheep breeds have higher oxygen carrying capacity and therefore more resistance to infectious disease. Among three breeds, Kage recorded the highest $\mathrm{Hb}$ concentration than others though it is not statistically significant. It could be because Kage can adapt in quite a range of altitude. $\mathrm{Hb}$ concentration for Baruwal and Lampuchhre breeds are comparable. The result of RBC shows that males had significant higher value than females, which is the reflection of health status of the breed studied. Breedwise variation in $\mathrm{RBC}$ value was also observed. Kage and 
Baruwal breed, which have been well adapted in higher altitude compared to lowland breedLampuchhre, have recorded higher value for $\mathrm{RBC}$ number, $\mathrm{Hb}$ and $\mathrm{PCV}$, which could provide evidence of the adaptation of these breeds to low atmospheric oxygen. The effect of altitude on erythrocyte values has been studied by many investigators and it is now a well-established fact that reduced oxygen tension in mountainous regions leads to an increased production and release of erythropoietin, thereby, stimulating erythropoiesis as a coping or adaptive mechanism to low oxygen level in such an environment (Tibbo et al., 2004).

PCV or Haematocrit value refers to percentage of whole blood comprises of RBC and therefore is crude marker of red cell number. The present study revealed that breed had no significant effect on $\mathrm{PCV}$ and $\mathrm{Hb}$ values. In contrast, the breed differences for these parameters was reported by (Forhead et al., 2002 and Jawasreh et al., 2009). Similarly, gender exhibited no significant effect on same parametres and this result concords with other workers (Tibbo et al., 2004; Shumaila et al., 2012). While Egbe-Nwiyi et al., (2000) reported the sex differences in HB and PCV of Nigeria sheep. PCV value in Nepalese breed (36.29 \pm 1.01$)$ was within physiological range and considerably higher than Iranian breeds $(27.35 \pm 3.16)$ which might be a sign of superior health status of Nepalese sheep.

The values of $\mathrm{MCV}, \mathrm{MCHC}$ and $\mathrm{MCH}$ are very important in the diagnosis of anemia and serve a useful index of the capacity of the bone marrow to produce red blood cells (Awodi et al., 2005). The MCV, MCHC and MCH values are greatly influenced by age and sex (Egbe-Nwiyi, 2000). In this study, MCHC value in Nepalese breed was higher than physiological range. The highly significant gender variation for MCV $(\mathrm{P}<0.01)$ and $\mathrm{MCH}(\mathrm{P}<0.05)$ where female showed the higher value than males.

The major functions of the white blood cell and its differentials are to fight infections, defend the body by phagocytocis against invasion by foreign organisms and to produce or at least transport and distribute antibodies in immune response. Thus, animals with low white blood cells are exposed to high risk of disease infection, while those with high counts are capable of generating antibodies in the process of phagocytocis and have high degree of resistance to diseases (Soetan et al., 2013) and enhance adaptability to local environmental and disease prevalent conditions (Kabir et al., 2011; Okunlola et al., 2012; Iwuji and Herbert, 2012; Isaac et al.,2013).The mean total WBC count obtained in this study fell within the normal physiological range, with majority of WBC made up of lymphocytes and neutrophils. Leucocyte cell distribution is affected by breed, temperature, environmental as well as body's demand and health status (Mbassa and Poulsen, 2003). Lymphocytic count was significantly lower in Kage breed compared to others while same breed recorded significant high value for neutrophil count. Males showed higher valued for lymphocytes than females while females showed higher value for neutrophils and this findingagrees with values (Egbe-Nwiyi et al., 2000) for sheep and goats in arid zone of Nigeria but contradicts with the record reported by Njidda et al., 2014. Monocytes were consistent for both breed and gender while Eosinophils and Basophils were undetectable in this study.

Serum biochemical indices is used to determine the level of heart attack, liver damage and to evaluate protein quality and amino acid requirements in animals (Harper et al., 1977). All biochemical parameters in this study were not significant for breeds while TP, Alb and P were observed statistically significant for gender. This result is consistent with earlier findings which 
illustrated the effect of breed on total protein, albumin was not significant (Gundogan, 2005). The value for TP in was less than normal physiological range, which might be attributed to poor nutrition. The biochemical parameters are usually influenced by nutrition level and closely associated with metabolic activity of individual animals (Shumaila et al., 2012). The breed difference for TP was observed where Kage breed recorded the highest value and Lampuchhre breed the lowest. Males exhibited significant higher value for TP than females. The Overall LS mean for Alb was observed higher than normal range and same parameter is significantly higher in females.

The result obtained for glucose value fell within normal physiological range for ovine species and females showed higher values than males. This value was found consistence among breeds. The value of glucose depends upon metabolic demand of body, exercise and diet. The value for calcium was consistent for both breed and sex while value for phosphrous was significantly higher in males. About $80 \%$ of the body phosphrous is present in the bones and teeth. The $20 \%$ in the soft tissues make up phosphor-protein, nucleoprotein, phospholipids, hexose phosphate and other compounds, which are essential in organ structure, nutrient transport and energy utilization.

\section{CONCLUSION}

The result of the preliminary study revealed that breed has no significant effect on all biochemical parameters under study and most of the haematological parameters except WBC indices. While most of the biochemical and haematological parameters were influenced by gender. The hematological and biochemical parameter values obtained from this study can be used as normal reference to assess health status of Nepalese breed of sheep. Further research with more number of samples is warranted for concrete information, which could be used to monitor animal health status to improve the management and conservation of these breeds.

\section{ACKNOWLEDGEMENT}

The authors are highly thankful to IAEA for providing required chemicals and to Central Veterinary Laboratory for research facilities to conduct this experiment. The authors also appreciate Mr. Dil Bahadur Gurung from Animal Breeding Division for his assistance to collect blood samples.

\section{REFERENCES}

Addass, P.A., David, D.L., Edward, A., Zira, K.E., and Midau, A. (2012). Effect of age, sex and management system on some haematological parameters of intensively and semi $\square$ intensively kept chicken in Mubi, Adamawa State, Nigeria. Iranian Journal of Applied Animal Science, 2(3): 277-282.

Addass, P.A., Midau, A. and Babale, D.M. (2010). Haemato-biochemical findings of indigenous goats in Mubi, Adamawa State, Nigeria. Journal of Agriculture and Social Sciences,6(1): 14-16.

Awodi, S., Ayo, J.O., Atodo, A.D. and Dzende, T.(2005), September. Some haematological parameters and the erythrocyte osmotic fragility in the Laughing Dove (Streptopella senegalensis) and the village Weaver bird (Ploceus cucullatus). In Proceedings of the 10th Annual Conference of Animal Science Association of Nigeria, 384-387. 
Braun, J.P., Trumel, C., and Bezille P. (2010). Clinical biochemistry in sheep: a selected review.Small Ruminant Research,92: 10-18.

Central Bureau of Statistics, (2016). Government of Nepal.

Coles, E.H., (1986). Veterinary Clinical Pathology. Fourth ed. Philadelphia: W.B. Saunders Company, 10-70.

Egbe-Nwiyi, T.N., Nwaosu, S.C. and Salami, H.A.(2000). Hematological values of apparently healthy sheep and goats as influenced by age and sex in arid zone of Nigeria.African Journal of Biomedicine Research,3: 109-115.

Forhead, A.J., Li, J., Glimour, R.S., Dauncey, M.J. and Fowden, A.L. (2002). Thyroid hormones and the mRNA of the GH receptor and IGFs in skeletal muscle of fetal sheep.Animal Journal of Physiology and Endocrinology Metabolism, 282(1): 80-86.

Gundogan, M. (2005). Some reproductive parameters and biochemical properties in Akkaraman and Awassi rams.Turkish Journal of Veterinary and Animal Sciences, 29: 595-599.

Harper, H.A., Rodwell, V.W., and Mayer, P.A. (1977). Review of physiological chemistry. The sixth $\mathrm{Ed}^{\mathrm{n}}$. California Lange Medical Publishers, 559-598.

Harvey, W.R. (1990). Mixed Model. Least squares and Maximum Livelihood Computer Program. Users' guide for LSMLMW and MIXMDL, PC-2 version.

Henderson, C.R. (1953). Estimation of variance and covariance components. Biometrics9: 226-252.

Isaac, L.J., Abah, G., Akpan, B. and Ekaette, I.U. (2013). Haematological properties of different breeds and sexes of rabbits.Proceedings of the $18^{\text {th }}$ Annual Conference of Animal Science Association of Nigeria, 24-27.

Iwuji, T.C. and Herbert, U. (2012). Haematological and serum biochemical characteristics of rabbit bucks fed diets containing garcimiola kola seed meal.Proceedings of the $37^{\text {th }}$ Annual Conference of Nigerian Society for Animal Production, 87-89.

Jawasreh, K., Awawdeh, F., Bani, I. Z.D., Al-Rawashdeh, O. and Al-Majali, A. (2009). Normal haematology and selected serum biochemical values in different genetic lines of Awassi ewes in Jordan. The internet Journal of Veterinary Medicine, 7(2): 1-6.

Kabir, M., Akpa, G.N., Nwagu, B.I., Adeyinka, I.A. and Bello, U.I. (2011). Sexual dimorphism, breed and age characteristics of rabbits in Zaria, Nigeria. Proceedings of the $16^{\text {th }}$ Annual Conference of Animal Science Association of Nigeria, 133137.

Mbassa, G.K. and Poulsen, J.S.D. (2003). Reference ranges for clinical chemical values in Landrace goats. Small Ruminant Research,10(2): 133-142.

Neopane, S.P. and Pokhrel. P.K., 2005. Indigenous cattle of Nepal. Nepal Agricultural Research Council (NARC), Khumaltar, Lalitpur.

Njidda, A., Shuai'Bu, A.A. and CE Isidahomen, A., (2014). Haematological and serum biochemical indices of sheep in semi-arid environment of northern Nigeria.Global Journal of Science Frontier Research, 14(2).

Oduye, O.O. and Adedevon, B.K. (1976). Biochemical Values of Apparently Normal Nigerian Sheep.Nigerian Veterinary Journal,5(1): 43-50.

Okunlola, D.O., Olorunisomo, A.O., Aderinola, A.O., Agboola, A.S., and Omole, O.G. (2012). Haematology and serum quality of red Sokoto goats fed Baobab (Adansonia digitata) fruit meal as supplement to guinea grass (Panicum maximum.Proceedings of the $17^{\text {th }}$ Annual Conference of Animal Science Association of Nigeria, 427-433. 
Oramari, R.A., Bamerny, A.O. and Zebari, H.M. (2014). Factors affecting some hematology and serum biochemical parameters in three indigenous sheep breeds.Advances in Life Science and Technology, 21: pp.56-63.

Polizopoulou, Z.S. (2010). Haematological tests in sheep health management. Small Ruminant Research, 92(1): pp.88-91.

Research Animal Resource [RAR]. (2009). Reference values for laboratory animals: Normal haematological values. RAR Websites, RAR, University of Minnesota. Retrieved from http://www.ahc.umn.edu/rar/refvalues.html.

Shumaila, K., Bhutta, A.M., Khan, B.A., Durrani, S., Ali, M., Ali, M. and Iqbal, F. (2012). Effect of age and gender on some blood biochemical parameters of apparently healthy small ruminants from Southern Punjab in Pakistan.Asian Pacific Journal of Tropical Biomedicine, 2(4): 304-306.

Šimpragaa, M., Šmucb, T., Matanović, K., Radina, L., Shek Vugrovećki, A., Ljubičić, I., Vojtaa, A. (2013). Reference intervals for organically raised sheep: Effects of breed, location and season on hematological and biochemical parameters. Small Ruminant Research,112: 1-6.

Soetan, K.O., Akinrinde, A.S., and Ajibade, T.O. (2013). Preliminary studies on the haematological parameters of cockerels fed raw and processed guinea corn (Sorghum bicolor).Proceedings of $38^{\text {th }}$ Annual Conference of Nigerian Society for Animal Production, 49-52.

Tibbo, M. Aragaw, K. Jibril, Y. Woldemeskel, M. Dawo, F. Rege, J.E.O. (2004). Factors Affecting Hematological Profiles in three Ethiopian Indigenous Goat Breeds.International Journal of Applied Research on Veterinary Medicine,2(4): 297-309. 